\title{
O perdão do ofendido na cultura jurídico-penal brasileira do século XIX: negociação no século da justiça pública? ${ }^{1}$
}

\author{
The victim's remission in Brazilian legal penal culture in the \\ XIX century: negotiation in the century of public justice?
}

Arley Fernandes Teixeira²

Universidade Federal de Minas Gerais - Belo Horizonte/MG

arleyft96@gmail.com

http://lattes.cnpq.br/6578378872619308

https://orcid.org/0000-0002-0964-5011

\begin{abstract}
Resumo: O presente trabalho tem como objetivo principal o estudo do perdão do ofendido, um instituto penal presente em ambos os códigos penais brasileiros do século XIX, o Código Criminal de 1830 e o Código Penal de 1890. A análise parte, sobretudo, dos livros jurídicos de direito penal e direito processual penal do Brasil no século XIX e procura, primeiramente, compreender o funcionamento legal desse instituto, quais seus critérios de aplicação e como funciona processualmente a capacidade destinada à parte em perdoar e, portanto, encerrar o processo em andamento e, a partir disso, adentrar nas mais importantes discussões doutrinárias sobre o perdão, das quais destacamos o problema dos miseráveis e a questão das ofensas físicas leves. Todas essas discussões tem o intuito geral de compreender o papel destinado às negociações penais no Brasil desse período, que, apesar de presentes ao longo de todo o século XIX,
\end{abstract}

1 Este artigo é resultado de uma pesquisa, orientada pelo prof. Ricardo Sontag, que foi financiada pela Fundação de Amparo à Pesquisa de Minas Gerais - FAPEMIG e faz parte do projeto, também financiado pela FAPEMIG, intitulado "História do direito penal brasileiro em perspectiva comparada", edital Demanda Universal n. 1/2017.

2 Graduando em Direito pela UFMG. Bolsista de Iniciação Científica FAPEMIG. 
passam por um momento de transformação no final desse século. Por fim, procurou-se posicionar essas discussões e conclusões no contexto de formação do Direito Penal Contemporâneo no Brasil, principalmente a partir da década de 1890 , uma década fundamental nessa mudança.

Palavras-chave: História do direito penal; perdão do ofendido; Brasil; Século XIX.

ABSTRACT: The present work has as its main objective the study of the victim's remission, a criminal institute present in both Brazilian penal codes of the nineteenth century, Criminal Code of 1830 and Penal Code of 1890. The analysis is based, above all, on the legal books on criminal law and criminal procedural law of Brazil in the nineteenth century and seeks, firstly, to understand the legal functioning of this institute, the criteria of application and how works the part's capacity to forgive and, therefore, to close the process in progress and, from there, to enter into the most important doctrinal discussions on forgiveness, from which we highlight the problem of the miserable and the issue of slight physical offenses. All these discussions have the general purpose of understanding the role of criminal negotiations in Brazil during this period, which, although present throughout the nineteenth century, suffered a transformation in the end of this century. Finally, we sought to position these discussions and conclusions in the context of the formation of contemporary criminal law in Brazil, especially since the 1890 s, a fundamental decade in this change.

KEYwords: History of Criminal Law; Victim's remission; Brazil; Nineteenth century.

SUMÁRIO: Introdução; 1. A afirmação da justiça hegemônica de aparato e a negociação penal: elementos inseparáveis de um longo processo; 2. O perdão do ofendido no Código Criminal de 1830: a internalização da negociação penal; 2.1 O perdão do ofendido no crime de ofensas físicas leves; $2.2 \mathrm{~A}$ polêmica questão do perdão do ofendido miserável; 3. O Código Penal de 1890 e o perdão do ofendido: "um produto anachronico de idéas metaphysicas"; Considerações Finais; Referências Bibliográficas. 


\section{INTRODUÇÃO}

Em análise das discussões na Câmara dos Deputados referentes ao Código Criminal do Brasil, aprovado em 22 de outubro de 1830, Rafael Mafei $^{3}$ conclui que durante o processo de criação dessa lei, o critério prático foi mais importante do que discussões teóricas e ideológicas de direito penal. Esse critério girava em torno de dois pontos centrais, a necessidade de substituição do Livro V das Ordenações, então considerado uma "legislação bárbara", atrasada, e a pacificação social através de legislação repressiva. Algumas questões penais que já ganhavam força na Europa ${ }^{4}$ e nos Estados Unidos não foram sequer discutidas pelos legisladores brasileiros, não por desconhecimento, mas pela necessidade de apressar e viabilizar a "modernização" da legislação penal brasileira.

Esse senso prático que guiava as discussões sobre a criação do código, no entanto, não impede de defini-lo como um importante marco, apesar de não o definitivo, na formação do direito penal contemporâneo no Brasil. Mafei ${ }^{5}$ explica que diversos elementos centrais para o que se entende atualmente por direito penal ainda não estavam presentes, ou completamente formados, no direito penal oitocentista brasileiro, como a divisão entre parte geral e parte especial, a independência do direito penal enquanto disciplina teórica, bem como a sua colocação no binômio direito público e privado e, ainda, a divisão teórica entre o que é direito processual e o que é direito material. Apesar disso, é possível dizer que os temas centrais do que se entende por direito penal contemporâneo, isto é, eficiência da punição, centralização política do poder punitivo e controle

3 QUEIROZ, Rafael Mafei Rabelo. A teoria penal de P. J. A. Feuerbach e os juristas brasileiros do século XIX: a construção do direito penal contemporâneo na obra de P. J. A. Feuerbach e sua consolidação entre os penalistas no Brasil. Tese (Doutorado em Direito) - Faculdade de Direito da Universidade de São Paulo, São Paulo, 2008, p. 243.

4 Sobre o tema recomendo: TARELLO, Giovanni. O problema penal no século XVIII. In: DAL RI JÚNIOR, Arno; SONTAG, Ricardo. História do direito penal entre medievo e modernidade, Belo Horizonte: Del Rey, 2011. p. 219-231.

5 QUEIROZ, Rafael Mafei Rabelo. A teoria penal de P. J. A. Feuerbach e os juristas brasileiros do século XIX: a construção do direito penal contemporâneo na obra de P. J. A. Feuerbach e sua consolidação entre os penalistas no Brasil. Tese (Doutorado em Direito) - Faculdade de Direito da Universidade de São Paulo, São Paulo, 2008, p. 248. 
de arbitrariedades não apenas estavam presentes no nosso primeiro código criminal, como são centrais para a sua compreensão. São esses os três elementos que Mafei chama de macrotemas do direito penal contemporâneo.

Para a proposta desse artigo, dois desses pontos são essenciais para a compreensão do porquê se estudar o perdão do ofendido: a eficiência da punição e a centralização política do poder punitivo. O primeiro deles refere-se à estratégia do chamado direito penal moderno, que desde o século XVIII com Beccaria e, posteriormente, com Bentham, entende a importância do efetivo cumprimento da pena, seja por motivos de exemplaridade e, portanto, como uma forma de desestimular a prática do crime, quanto como uma maneira de retribuição ao mal do delito. Em ambas funções a certeza e eficiência da punição é essencial, mesmo que, para tanto, o rigor das leis penais presentes nas ordenações, entre elas o Livro V das Ordenações Filipinas, seja duramente criticado e suprimido em prol de uma legislação mais branda abstratamente, mas que efetivamente possa ser cumprida.

Sobre o segundo ponto, convém citar Mario Sbriccoli, ao escrever sobre a formação da penalística italiana, afirma que o século XIX é um período em que a questão penal ganha uma forte conotação política. $\mathrm{Na}$ Itália isso é ainda mais evidente, visto a clara relação entre o processo de unificação política nos anos 1860 e a forma com que os juristas deveriam pensar um Código Penal unitário e centralizador ${ }^{6}$, porém, o Brasil também segue uma lógica similar sobre esse aspecto. Com a independência política em relação a Portugal, em 1822, e a elaboração da Constituição do Império de 1824, o Código Criminal e o Código Civil são os dois alicerces faltantes da formação político-jurídico do Brasil. Nesse mesmo período, o país ainda vivia um período tenso politicamente, marcado pela fragilidade institucional, tanto que apenas um ano após a promulgação do Código Criminal de 1830, inicia-se uma série de revoltas populares no Brasil, chamadas de revoltas regenciais. Nesse contexto, portanto, o Código Criminal tem um forte apelo centralizador e isso reflete, tendencialmente, nos institutos nele presentes.

6 SBRICCOLI, Mario. La penalistica civile. Teorie e ideologie del diritto penale nell'Italia unita. In: SBRICCOLI, Mario. Storia del diritto penale e della giustizia, Milão: Giuffrè, v. 2, 2009, p. 515. 
O objetivo desse trabalho é compreender e analisar as disposições legais e discussões doutrinais acerca do perdão do ofendido, um instituto com características bastante particulares, tanto pelo seu caráter negocial e privado, em um contexto de centralização política e eficiência punitiva, quanto, como se verá, pela maneira como essa lógica foi incorporada ao direito penal contemporâneo, processo que chamei de internalização. Com isso, segui uma linha um pouco diferente do habitual, na medida em que busquei, em um instituto que não corresponde exatamente às características gerais do direito penal do período, algumas respostas que ajudassem a desvendar a maneira como se processam esses macrotemas do direito penal contemporâneo no Brasil oitocentista.

A ideia, portanto, é esclarecer questões chaves, tais como: em quais crimes o perdão poderia ser aceito como meio de extinguir o processo? Qual o critério utilizado para a escolha desses crimes? Em que momento do processo isso poderia ser feito? Quem pode perdoar? Existe diferença entre a aplicação do perdão do ofendido nos códigos de 1830 e de 1890? E, então, propor uma interpretação desses dados extraídos, que auxilie na compreensão do direito penal e direito processual penal brasileiro do século XIX, em especial no que se refere ao seu caráter ainda negocial e privado.

Para tanto, nos ocuparemos, sobretudo, dos livros de doutrina de direito penal material e processual, além, é claro, das fontes legislativas, em especial o Código Criminal de 1830, o Código de Processo Criminal de 1832, o Código Penal de 1890 e, eventualmente, a Constituição Imperial de 1830 e a Constituição Republicana de 1891. Além disso, serão utilizados dados extraídos da Hemeroteca Digital da Biblioteca Nacional, pesquisados em diversas revistas do período.

Dessa forma, estudar o perdão do ofendido no século XIX é conduzido por dois motivos fundamentais: trata-se de um instituto penal sobre o qual há ainda uma importante lacuna historiográfica a ser preenchida, panorama bastante diferente de países como Espanha, Itália e França, nos quais há escritos historiográficos relevantes especificamente sobre o perdão da vítima ${ }^{7}$; estudar esse instituto vai além de compreender o

7 PADOA-SCHIOPPA, Antonio. Delitto e pace privata. In: Italia ed Europa nella storia del diritto, Bologna: Il Mulino, 2008. p. 209-229; TOMÁS Y VALIENTE, 
seu mecanismo de funcionamento e extensão, trata-se de compreender uma lógica penal diversa da atual, de forma a desnaturalizar determinados paradigmas que parecem imutáveis aos olhos contemporâneos ${ }^{8}$, o que pode lançar um olhar diferente sobre problemas atuais, como por exemplo sobre a discussão geral acerca do papel da vítima no processo penal, ou mesmo em casos mais pragmáticos, como a disponibilidade ou não da ação penal na lei Maria da Penha.

\section{A AFIRMAÇÃo dA JUSTIÇA HEGEMÔNICA de APARATO E A NEGOCIAÇÃO PENAL: ELEMENTOS INSEPARÁVEIS DE UM LONGO PROCESSO}

Antes de iniciar propriamente o estudo sobre o perdão do ofendido, convém fazermos uma pequena análise de algumas premissas fundamentais que são chave para a interpretação proposta neste artigo. Por mais que o objeto de estudo em questão esteja localizado no século XIX, esse período não pode ser analisado de forma isolada dos demais, visto que é um ponto em uma linha de processos contínuos e descontínuos, de forma que o que ocorre antes e o que acontece depois são parte desse movimento.

A formação do direito penal moderno pode ser analisada, segundo Mario Sbriccoli ${ }^{9}$, como um movimento de fuga da vingança privada, de consolidação do monopólio estatal da violência. Se durante o período pré-moderno, em especial antes do século XIII, a solução dos conflitos penais era realizada, sobretudo, de forma consensual entre as partes,

Francisco. El perdón de la parte ofendida en el derecho penal castellano ( $\mathrm{Si}$ glos XVI, XVII e XVIII). In: Anuario de historia del derecho español, n. 31, 1961; D’AMELIO, G., Indagini sulla transazione nella dottrina medievale, Roma, 1971; NICCOLI, Ottavia., Perdonare. Idee, pratiche, rituali in Italia tra Cinque e Seicento, Roma, Bari, 2007; ALESSI, Giorgia. I patti della giustizia. L'inestirpabile vocazione transattiva del Regno di Napoli, in CAVINA, M. La giustizia criminale nell'Italia moderna, Bologna, 2012.

8 HESPANHA, Antônio Manuel. Cultura jurídica europeia: síntese de um milênio, Coimbra, 2012, p. 48.

9 SBRICCOLI, Mario. Justiça Criminal. Discursos Sediciosos, Rio de Janeiro: Revan, n. 17/18, 2011, p. 459. 
utilizando-se de práticas privadas de solução de conflitos, no fim da Idade Média e, especialmente após o século XVI, o poder público percebe a importância do controle estatal da violência e da necessidade de intervenção do Estado, a fim de garantir um processo penal mais efetivo e tutelador da ordem pública. A violência e a criminalidade não são mais entendidas como um problema de ordem privada, o delito é também uma ofensa à comunidade e, como tal, deve ser combatido de forma sistêmica, sem depender da vontade, ou mesmo da ação da vítima. Nesse contexto, Estado e sociedade são as grandes vítimas do crime.

Massimo Meccareli ${ }^{10}$ escreve como esse processo de publicização do direito penal, a partir da segunda metade do século XIII, é baseado em um paradigma diferente do sistema comunitário anterior. A coincidência entre a formação dos contornos desse modo de justiça penal pública e da própria figura do Estado Moderno permite dizer que é, a partir desse momento que se começa a construir um sistema de princípios e garantias na ordem penal, no qual o Estado é um ponto central dessa mudança.

Nesse processo, o século XIX é um período bastante importante. Entre as características mais relevantes desse modelo novo de justiça estão a lei, criada por um representante estatal e o único critério de justiça a ser utilizado, a ação e a prova, elementos intrínsecos do processo penal, a pena, que é a afirmação da justiça e os aparatos, ou seja, a forma como aquele modelo vai se desenvolver, com suas estruturas e instituições públicas. Esse seria o ponto alto de um processo que se iniciou no final do medievo, que Sbriccoli ${ }^{11}$ chama de justiça hegemônica de aparato.

Durante a Idade Média e o Antigo Regime, as práticas de transação penal (como o perdão do ofendido, as negociações de paz, as tréguas, concórdias, ou ainda a chamada pace privata, que incluía toda uma série de contratos extrajudiciais, em que, geralmente, uma parte perdoa a outra pela prática de um crime) tinham uma relevância muito grande na

10 MECCARELLI, Massimo. Regimes jurídicos de exceção e sistema penal: mudanças de paradigma entre Idade Moderna e Contemporânea. In: DAL RI JÚNIOR, Arno; SONTAG, Ricardo (org.). História do direito penal entre medievo e modernidade. Belo Horizonte: Del Rey, 2011, p. 87-110.

11 SBRICCOLI, Mario. Justiça Criminal. Discursos Sediciosos, Rio de Janeiro: Revan, n. $17 / 18,2011$, p. 461. 
estrutura penal. ${ }^{12}$ Influenciada pelas ideias de pensadores como Bentham e Beccaria, as legislações penais modernas tendem a restringir fortemente os espaços de influência privada no processo criminal. Não por acaso, Beccaria separa um capítulo do seu livro para tratar das graças, no qual critica a possibilidade do perdão da vítima como meio de extinção do processo penal, afirmando que:

Às vezes, abstemo-nos de punir um crime pouco importante, quando o ofendido perdoa. É um ato benevolente, sem dúvidas, porém contrário ao interesse público. Um particular pode perfeitamente não exigir que seja reparado o mal que se lhe causou; porém o perdão que ele dá não pode destruir a necessidade do exemplo. ${ }^{13}$

O autor prossegue afirmando que o direito de punir não pertence especificamente a nenhum cidadão, mas à coletividade, de forma que um indivíduo não pode, através de uma escolha solitária, impedir que a sociedade, representada pelo Estado, puna o agressor. De acordo com Beccaria, a partir do momento em que as penas forem abrandadas, de forma que possam ser efetivamente cumpridas, o perdão e a graça são desnecessários, visto que só são úteis em vista da injustiça das penas pré-modernas.

A mudança de papel da transação penal do final do século XVIII e, sobretudo no século XIX, época das codificações penais, vai além de uma mudança quantitativa, é uma alteração na sua estrutura.

Essa é a premissa fundamental para se entender o papel do instituto do perdão do ofendido, na forma como foi pensado para o Código Criminal de 1830. Apesar das intensas mudanças teóricas pelo qual passou o direito penal no século XVIII, com o início do que pode ser chamado de direito penal moderno e a recusa cada vez mais intensa às práticas de transação penal, que possui na figura dos códigos a sua máxima expressão, a tensão entre a esfera privada e pública do direito penal ainda sobrevive. Em relação à chamada "prestação de contas dos códigos em

12 PADOA-SCHIOPPA, Antonio. Delitto e pace privata. In: PADOA-SCHIOPPA, Antonio. Italia ed Europa nella storia del diritto, Bologna: Il Mulino, 2008. p. 209-229.

13 BECCARIA, Cesare. Dos delitos e das penas, São Paulo: Martin Claret, 2014, p. 59. 
relação às práticas sociais", descrita por Sbriccoli, eu preferiria chamar de internalização das negociações penais. Visto que não se podia ignorar muitas dessas práticas, a estratégia do poder público foi de internalizá-las, controlá-las. Não por acaso, a Constituição do Império de 1824, seguindo o modelo da Constituição Francesa de 1814, prevê nos art. 161 e art. 162 a necessidade de que em todas as causas, cíveis ou criminais, haja uma tentativa anterior de reconciliação, realizada pelo então Juiz de Paz. ${ }^{14}$

Nesse mesmo contexto, o perdão do ofendido também pode ser entendido como parte dessa estratégia. Tómas y Valiente estudou o perdão na Espanha nos séculos XVI ao XVIII, e as suas conclusões são de suma importância para a nossa análise. O primeiro ponto levantado pela sua pesquisa diz respeito à amplitude do perdão, que era aceito em diversos crimes, incluindo homicídios, estupro, rapto, lesões corporais, dentre outros, o que nos leva a crer que há uma forte interferência privada da vítima no processo penal. Porém, essa impressão é compensada pelos efeitos jurídicos restritos concedidos ao perdão da vítima, que nem sempre eximia o réu de cumprir as penas ou encerrava um processo penal em curso. Valiente ${ }^{15}$ cita casos em que o perdão até mesmo servia de modo contrário ao desejado pelas partes, como prova de confissão do crime pelo réu. Pelos casos analisados pelo autor, a consequência mais comum advinda do perdão da vítima era a não imposição de penas corporais, o que corresponde a boa parte das penas previstas para os delitos na legislação espanhola em vigor no período, e como requisito para a análise de graça, isto é, o perdão real. Apenas em poucas situações, nas quais se destaca o delito de adultério, o perdão do ofendido tinha eficácia plena. ${ }^{16}$

Valiente identifica mesmo uma tentativa do poder público espanhol de controlar as práticas de transação penal, mesmo que, porventura,

14 “Art. 161. Sem se fazer constar, que se tem intentado o meio da reconciliação, não se começará Processo algum. Art. 162. Para este fim haverá juizes de Paz, os quaes serão electivos pelo mesmo tempo, e maneira, por que se elegem os Vereadores das Camaras. Suas attribuições, e Districtos serão regulados por Lei."

15 TOMAS Y VALIENTE, Francisco. El perdón de la parte ofendida en el Derecho penal castellano (siglos XVI, XVII y XVIII). In: Anuario de historia del derecho español, n. 31, 1961, p. 93.

16 TOMAS Y VALIENTE, Francisco. El perdón de la parte ofendida en el Derecho penal castellano (siglos XVI, XVII y XVIII). In: Anuario de historia del derecho español, n. 31, 1961, p. 92-93. 
algumas dessas tentativas tenham sido fracassadas, como no caso do controle do perdão por preço. Interessa observar também que, mesmo em um período de consolidação do que Sbriccoli chama de justiça hegemônica de aparato, é possível identificar ainda forte presença de práticas transacionais, de interferência privada no processo penal e o papel forte da vítima em matéria criminal.

Porém, resta saber como essa relação se desenvolve no século XIX, um período marcado pelos códigos penais e pelo seu caráter centralizador e absoluto. Valiente faz uma interessante ressalva sobre isso:

[...] en general estos três siglos constituyen una época en que las líneas y las ideas básicas del Derecho Penal permanecen sin modificación sustancial; habrá que esperar a los primeros decenios del XIX para que una nueva mentalidad (ciertamente latente desde la segunda mitad del siglo XVIII en algunes sectores y ambientes) salga a luz e imponga nuevos enfoques y nuevas bases del Derecho Penal. Entonces será cuando la institución que aquí nos ha ocupato sufrirá alteraciones importantes. ${ }^{17}$

Ainda que Valiente tenha escrito esse trecho para o contexto espanhol, nada nos impede de pensar as diferenças entre a instituição do perdão do ofendido no século XIX no Brasil e as descritas pelo autor, com a devida contextualização. Além de pontuar essas diferenças, a análise desse instituto nas páginas seguintes nos ajudará a compreender um pouco da maneira como o direito penal se desenvolveu no Brasil Imperial e início da República, e na relação entre código e práticas sociais, sobretudo no que diz respeito às transações penais.

\section{O perdão do ofendido no Código Criminal de 1830: A INTERNALIZAÇÃO DA NEGOCIAÇÃo PENAL}

Diferente da legislação francesa, do projeto de código penal da Lombardia e do Código Leopoldino, três grandes referências em termos

17 TOMAS Y VALIENTE, Francisco. El perdón de la parte ofendida en el Derecho penal castellano (siglos XVI, XVII y XVIII). In: Anuario de historia del derecho español, n. 31, 1961, p. 94. 
de legislação penal do final do século XVIII e início do século XIX, o primeiro código criminal brasileiro, em 1830, tem um artigo específico para regular o perdão da vítima, o art. 67: "O perdão do offendido antes, ou depois da sentença, não eximirá das penas em que tiverem, ou possam ter incorrido, aos réos de crimes publicos, ou dos particulares, em que tiver lugar a accusação por parte da Justiça"18. Um dispositivo que, à primeira vista, parece perfeitamente de acordo com o esperado, isto é, de proibição de que o perdão da vítima impeça a punição estatal, mas que, através dessa conceituação negativa, ou seja, definindo quais as possibilidades de não aplicação do perdão, estabelece também, por exclusão, quais os crimes em que a vítima pode perdoar o réu, extinguindo, portanto, o processo penal, ou até mesmo a aplicação da pena em caso de condenação.

O art. 67 faz referência a duas classes de delitos, crimes públicos e crimes particulares com acusação por parte da Justiça, que são parte da classificação dos crimes adotada pela nossa lei. O Código de 1830 prevê três grandes espécies de crimes, públicos, policiaes e particulares. Os dois primeiros são denunciados diretamente pelo promotor público e não podem ser perdoados.

Já os crimes particulares são aqueles que, em regra, dependem da queixa da parte ofendida para a punição, ou seja, são aqueles crimes que afetam mais a esfera privada do que a pública e que, por isso, em regra não poderiam ser denunciados diretamente pelo promotor público, dependendo da manifestação da parte ofendida ${ }^{19}$. Mas, aqui, já um primeiro elemento que causa estranheza aos olhos contemporâneos: as espécies de delitos classificados como particulares. Nessa parte do código estão previstos crimes como o homicídio, roubo, furto e diversos outros que, atualmente, são classificados, sem maiores problemas, como públicos. Mesmo à época, essa classificação não passou despercebida. Thomaz Alves Junior, ao comentar sobre isso, afirmou que:

18 BRASIL. Codigo criminal do Império do Brazil de 16 de dezembro de 1830. Disponível em: <http://www.planalto.gov.br/ccivil_03/Leis/LIM/LIM-16-121830.htm> Acesso em: 07/08/2018.

19 SOUZA, Braz Florentino Henriques de. Codigo criminal do Imperio do Brasil: annotado com as leis, decretos, avisos e portarias, Recife: Typ. Universal, 1858, p. 74. 
Acreditamos que esta divisão não é tão completa e frisante que possa ficar isenta de toda e qualquer imputação ou defeito; principalmente quando encontramos na parte analytica dos crimes, vemos que sem razão se vêm qualificados de crimes particulares crimes que sem dúvida atacão a vida e segurança pública. ${ }^{20}$

E logo em seguida prosseguiu, afirmando: "E qual é o crime que não ataca a ordem e segurança pública? Todo o crime tem esse ataque, e por isso esse rigor da expressão - todo o crime é público - porque ofende a ordem e segurança pública.” ${ }^{11}$. O autor estranha que determinados delitos no código sejam considerados particulares, provavelmente se referindo aos citados anteriormente e, complementa, afirmando que, em última análise, todos os crimes são públicos, por ofenderem a ordem e a segurança pública.

Entretanto, apesar da nomenclatura e da estranheza proporcionada pela presença de determinadas espécies de crimes na categoria de particulares, era possível que, em determinados delitos particulares, o promotor público denunciasse. Esses são os chamados delitos particulares com acusação por parte da Justiça, sobre o qual o art. 67 faz referência.

Ou seja, a ação pública e a ação privada, diferente do que possa parecer a princípio, não são os instrumentos exclusivos para o início do processo penal nos crimes públicos e crimes particulares, respectivamente. Isso porque é possível que a parte acuse em crimes públicos, chamado por Pimenta Bueno de ação popular, prevista no art. $157^{22}$ da Constituição Política Imperial de 1824, bem como também é possível que o promotor público acuse em determinados delitos privados. Em relação ao perdão da vítima, entender essa lógica é fundamental, visto que a penalização ou o processo penal só serão extintos nos casos em que a parte acuse e o crime seja particular. Isto é, mesmo quando a parte acuse (ação popular)

20 ALVES JUNIOR, Thomaz. Anotações teóricas e práticas ao Código Criminal, Rio de Janeiro: Francisco Luiz Pinto \& C. editores, 1864, p. 49.

21 ALVES JUNIOR, Thomaz. Anotações teóricas e práticas ao Código Criminal, Rio de Janeiro: Francisco Luiz Pinto \& C. editores, 1864, p. 49.

22 Art. 157. Por suborno, peita, peculato, e concussão haverá contra elles acção popular, que poderá ser intentada dentro de anno, e dia pelo proprio queixoso, ou por qualquer do Povo, guardada a ordem do Processo estabelecida na Lei. (Grifos meus) 
nos crimes públicos, o perdão da vítima não tem qualquer efeito, da mesma forma que nas situações em que há acusação pública em crimes particulares, o perdão do ofendido não extingue a penalização. ${ }^{23}$

Em síntese, portanto, quando se fala em crimes particulares, são esses os cenários possíveis de acusação: a) quando se trata de crime particular com acusação oficial, o processo pode iniciar-se pela denúncia do promotor público ou popular (ação pública em ambos os casos) ou pela queixa da parte (ação privada), de forma que se a parte optar pela acusação nessa classe de delitos, a ela não será concedido, posteriormente, o direito de perdoar o ofensor, pois, tal como explicado por Pimenta Bueno ${ }^{24}$, o Ministério Público tem igual direito de propor a acusação nessa classe de delitos; b) no caso de crime particular sem acusação oficial, desde que não se encaixe nas outras circunstâncias analisadas a seguir, como flagrante delito ou miserabilidade da parte, o processo somente iniciará mediante queixa, sob a forma da ação privada, a qual, nesse caso, admite o perdão do ofendido como extintor do processo ou da pena.

Além disso, é importante observar aqui como a queixa não era restrita aos casos de crimes puramente privados, tal como se verá a partir do Código Penal de 1890, mas se estendia também aos crimes particulares com acusação oficial, como homicídio, roubo, entre outros. Nesse sentido, portanto, a lógica presente no século XIX era a da acusação privada em todos os crimes particulares, a parte terceira do Código Criminal de

23 Montenegro defende a tese de que o perdão da vítima nos delitos particulares com acusação pública diz respeito somente à satisfação do dano (MONTENEGRO, Manoel Januário Bezerra. Lições acadêmicas sobre artigos do codigo criminal. Recife: Typographia Universal, 1860, p. 450). Da mesma forma, Alves Junior afirma que: "Nestes casos de acusação pelo ministério público o perdão do offendido não faz desaparecer o efeito da pena, e só a obrigação da satisfação do damno causado, porque a justiça tem acção, e não lhe é lícito transigir”. O mesmo Alves Junior afirma que o efeito de extinguir a necessidade de satisfação do dano ocorre nas situações de delito particular sem acusação oficial, o que faz, de acordo com o autor, que o perdão da vítima seja mais amplo do que o perdão do Imperador (Graça), visto que nesse último, não há extinção da obrigação de ressarcir o dano causado (ALVES JUNIOR, Thomaz. Anotações teóricas e práticas ao Código Criminal. Rio de Janeiro: Francisco Luiz Pinto \& C. editores, 1864, p. 660-661).

24 PIMENTA BUENO, José Antônio. Apontamentos sobre o processo criminal, Rio de Janeiro: Empreza Nacional do Diario, 1857, p. 78. 
1830, com exceções em que há também possibilidade de denúncia, caso dos crimes particulares com acusação oficial.

Pois bem, para se compreender os casos em que é possível o perdão do ofendido basta se entender os critérios de diferenciação entre os delitos particulares sem acusação particular e os com acusação oficial. O art. 74 do Código de Processo Criminal de 1832 ajuda a responder essa pergunta. Esse artigo prevê seis hipóteses legais em que a acusação é feita pelo Promotor Público:

Art. 74. A denuncia compete ao Promotor Publico, e a qualquer do povo:

$\S 1^{\circ}$ Nos crimes, que não admittem fiança.

$\S 2^{\circ}$ Nos crimes de peculato, peita, concussão, suborno, ou qualquer outro de responsabilidade.

$\S 3^{\circ}$ Nos crimes contra o Imperador, Imperatriz, ou algum dos Principes, ou Princezas da Imperial Familia, Regente, ou Regencia.

$\S 4^{\circ}$ Em todos os crimes publicos.

$\S 5^{\circ}$ Nos crimes de resistencia ás autoridades, e seus officiaes no exercicio de suas funcções.

$\S 6^{\circ}$ Nos crimes em que o delinquente fôr preso em flagrante, não havendo parte que 0 accuse. ${ }^{25}$

A primeira delas diz respeito aos delitos que não admitem fiança, instituto regulado pelo capítulo VIII do Título II, Parte Segunda do Código de Processo Criminal, modificado posteriormente pela Lei n. 261, de 3 de dezembro de 1841. De acordo com o art. 101 do Código de Processo Criminal: “Art. 101. A fiança não terá lugar nos crimes, cujo maximo da pena fôr: $1^{\circ}$ morte natural: $2^{\circ}$ galés: $3^{\circ}$ seis annos de prisão com trabalho: $4^{\circ}$ oito annos de prisão simples: $5^{\circ}$ vinte annos de degredo." ${ }^{26}$

25 BRASIL. Codigo de processo criminal de primeira instância de 29 de novembro de 1832. Disponível em: <http://www.planalto.gov.br/ccivil_03/leis/LIM/ LIM-29-11-1832.htm> Acesso em: 07/08/2018.

26 BRASIL. Codigo de processo criminal de primeira instância de 29 de novembro de 1832. Disponível em: <http://www.planalto.gov.br/ccivil_03/leis/LIM/ LIM-29-11-1832.htm> Acesso em: 07/08/2018. 
A segunda, terceira e quarta hipóteses previstas no art. 74 se referem a uma mesma classe de delitos, os crimes públicos e poderiam ser resumidos pelo $\S 4^{\circ}$, isto é, em todos os crimes públicos há acusação pelo promotor público. A quinta possibilidade de denúncia pública referese aos delitos de resistência à autoridade no exercício das suas funções, classe em que o perdão da vítima não tem qualquer efeito jurídico.

A última das situações previstas nesse dispositivo diz respeito à situação de flagrante delito. De acordo com esse artigo, nos crimes em que o delinquente é preso em flagrante, não havendo parte que o acuse, a denúncia é feita pelo promotor público e o perdão do ofendido não teria qualquer efeito legal, independente do tipo de crime cometido. Azevedo $^{27}$ elenca algumas complicações na prática criminal derivadas dessa disposição. A primeira questão refere-se à seguinte situação: um réu, preso em flagrante pela prática de um crime particular, é acusado pelo ofendido. Porém, durante a acusação, o ofendido decide perdoar o ofensor, desistindo, portanto, da ação penal; nesse caso, o promotor público pode prosseguir com a acusação pública ou o processo deve ser encerrado? O autor defende a tese de que, sendo o crime particular passível de acusação pública, isto é, enquadrado em alguma das outras hipóteses do art. 74, o promotor público tem o dever de acusar. Da mesma forma, mesmo que seja um crime puramente particular, também chamado de delito particular sem acusação pública, o promotor público ainda assim deve acusar, visto que a desistência do ofendido não muda a circunstância no momento do crime, ou seja, o flagrante delito.

Todavia, Azevedo completa que não é isso o que decidem os práticos dos tribunais brasileiros, que, de acordo com o autor, optam pela interpretação literal da norma, visto que na parte final do $\S 6^{\circ}$ há a seguinte redação: "não havendo parte que o accuse". Dessa forma, entendem os tribunais que, por ter ocorrido a acusação privada, está revogada a permissão do promotor público em acusar, retornando o crime ao estado inicial de delito puramente particular, já que a lei permite atuação do promotor público apenas nas situações em que não há

27 AZEVEDO, Manoel Mendes da Cunha. Observações sobre vários artigos do código de processo criminal e outros da lei de 3 de dezembro de 1841, Pernambuco: Typographia da Viuva Roma, 1852, p. 59. 
parte que acuse. De acordo com esse entendimento, o perdão da vítima encerraria o processo penal.

Porém, para Azevedo, o que parece apenas uma interpretação literal da norma penal é, na verdade, uma escolha com fundamento teórico mais profundo, oriunda do que ele chama dos Tratadistas, que estudam a jurisprudência criminal inglesa. O autor não desenvolve melhor essa ideia, mas essa referência à Inglaterra pode ser explicada pela diferença do processo criminal nos países de Common Law, nos quais predomina a lógica de disputa entre as partes, defesa e acusação, sendo, portanto, maior a influência e poder das partes. Mais adiante no mesmo livro, Azevedo ${ }^{28}$ ao comentar o art. 259 do Código de Processo Criminal ${ }^{29}$, afirma que esse dispositivo é uma "imitação cega e irrefletida" do sistema inglês, pois permite às partes transigir sobre quais fatos podem ser levados a exame pelos jurados. Isso por que no Júri Inglês as partes poderiam transigir sobre tudo, inclusive sobre a quantidade de pena, mas no sistema adotado no Brasil não, de forma que se os jurados devem decidir a pena a ser aplicada, a eles não podem faltar todos os fatos necessários para tal. Completa o autor que:

Em Inglaterra, a excepção de tres, todos os mais crimes são de simples acusação particular, e as partes transigindo, renuncião até certo ponto hum direito, que he seu, não obstante ser submettido á acção da Justiça publica; mas entre nós quasi todos os crimes hoje, a excepção de poucos, pertencem á accusação do ministerio publico, que representa o direito punitivo da sociedade, contra cujos interesses as partes não podem transigir. ${ }^{30}$

28 AZEVEDO, Manoel Mendes da Cunha. Observações sobre vários artigos do código de processo criminal e outros da lei de 3 de dezembro de 1841, Pernambuco: Typographia da Viuva Roma, 1852, p. 163.

29 "Art. 259. Formado o segundo Conselho, que deve ser de doze Jurados, guardadas todas as formalidades que estão prescriptas para a formação do primeiro, e prestado o mesmo juramento, o Juiz de Direito fará ao accusado as perguntas, que julgar convenientes sobre os artigos do libello, ou contrariedade; e aquelles factos sobre que as partes concordarem assignando os artigos, que lhes forem relativos, não serão submettidos ao exame dos Jurados. (Grifos nossos)"

30 AZEVEDO, Manoel Mendes da Cunha. Observações sobre vários artigos do código de processo criminal e outros da lei de 3 de dezembro de 1841, Pernambuco: Typographia da Viuva Roma, 1852, p. 164-165. 
Isso ajuda a entender o porquê de Azevedo mencionar que os práticos dos tribunais brasileiros, ao permitir o perdão do ofendido no caso de flagrante delito, são influenciados pelo pensamento criminal inglês. O sistema inglês fornece maior poder às partes ${ }^{31}$, é um sistema mais acusatório e menos inquisitório, adotando a clássica divisão entre os modos processuais penais ${ }^{32}$ e, de acordo com o pensamento do autor, apenas em um sistema em que a maioria dos crimes é de acusação particular é que seria possível a escolha por permitir à vítima perdoar ofensor em uma situação de flagrante delito. Nesse sentido, o pensamento dos práticos brasileiros nesse caso não é, pelo que pode ser interpretado do que Azevedo escreve, uma simples interpretação literal da norma, mas a adoção de elementos de um sistema processual diferente.

Essa preocupação de Azevedo, de fato, faz todo sentido. Dantas ${ }^{33}$ faz uma interessante análise da influência da obra de Edward Livingston, em especial do System of Penal Law for the State of Lousiana, no processo de elaboração dos códigos Criminal de 1830 e de Processo Criminal de 1832. Entre as claras influências descritas pela autora destaca-se o júri, uma novidade para a época, advindo do sistema inglês e estadunidense. Não à toa o trecho discutido por Azevedo, acerca da capacidade de transigir das partes, está inserido no capítulo do júri, então considerado pelo autor como uma cópia de um modelo processual distinto.

E, claro, isso também é um reflexo do que vimos anteriormente sobre a tensão entre a esfera pública e privada no direito criminal no século XIX no Brasil. A adoção pelos tribunais da aceitação do perdão do ofendido na situação de flagrante delito que, de acordo com Azevedo, é oriunda de uma influência teórica inglesa, é um reflexo

31 HOSTETTLER, John. A history of Criminal Justice in England and Wales, UK: Waterside Press, 2009, p. 121.

32 Sobre essa dialética entre modo processual acusatório e inquisitório recomendo: MECCARELLI, Massimo. El proceso penal como lugar de determinación de la justicia. Algunas aproximaciones teóricas en la época del ius commune. In: MADERO, Marta. Procesos, inquisiciones, pruebas: homenaje a Mario Sbriccoli, Buenos Aires: Manantial, 2009. p. 307-323.

33 DANTAS, Monica Duarte. Da Luisiana para o Brasil: Edward Livingston e o primeiro movimento codificador no Império (o Código Criminal de 1830 e o Código de Processo Criminal de 1832). In: Jahrbuch fur Geschichte Lateinamerikas (1998) / Anuario de Historia de América Latina, v. 52, p. 117-205, 2015. 
de uma visão de processo criminal em que as partes, especialmente a vítima, possuem uma importância e uma atuação muito extensa, em um contexto, século XIX, em que o direito penal e, consequentemente, o processo penal se distancia cada vez mais das partes, tornando-se cada vez mais público.

Mas essa tensão ocorre apenas na ordem prática, nos tribunais?

Não, e a explicação para tanto está nos outros problemas elencados por Azevedo. Na situação de um processo de flagrante delito de crime puramente particular, em que a parte acusa durante todo o processo, o réu é condenado e, após a sentença condenatória, o ofendido o perdoa, esse perdão exime o réu do cumprimento da pena? Azevedo entende que sim, pois a acusação do promotor público na situação anterior se deve não à necessidade de punição, mas sim a uma espécie de resposta ao público que testemunhou um flagrante delito. Porém, e esse é o argumento central do autor, essa satisfação externa é inteiramente completa com a acusação, não necessita da punição, de forma que não se pode extrair disso a conclusão de que quem desiste do direito de acusar, perde o direito de perdoar.

Azevedo entende que são direitos diferentes e independentes, de forma que mesmo aquele que optou por não promover a acusação, gerando, portanto, a acusação pública, pode perdoar após sentença condenatória, visto que a especificidade do flagrante, para o pensamento do autor, exige somente a acusação, como uma forma de resposta pública àquela violação da lei estatal. $\mathrm{O}$ autor completa afirmando que:

[...] o perdão do offendido he sempre valioso; porque o perdão sendo hum acto todo de clemencia, e nascido dos instinctos piedosos da natureza humana, não pôde, sem se desconhecer a sua fonte, ficar dependente do direito de accusar, cujo exercicio pôde muitas vezes ser hum effeito de sentimentos reprovados. A doutrina opposta serviria para contrariar as vantagens da reflexão, e da emenda, se for promovida a accusação pelo desejo da vingança. Ella seria fatal ao offensor, e ao offendido: a este por ficar privado de reparar pelo perdão o mal, que fizera pelo odio, ou outro motivo semelhante; áquelle, a quem se nega o meio mais conducente de reconciliar-se com este, agradecido ao beneficio do perdão. Ella seria fatal á sociedade inteira, que 
tanto interessa na pratica das acções generosas, e benevolas, e na harmonia de seus membros dissidentes. ${ }^{34}$

Direito de perdoar e direito de acusar, portanto, são diferentes e independentes. Enquanto o primeiro tem origem nos melhores sentimentos humanos, o segundo pode estar atrelado a sentimentos ruins, como o desejo de vingança, de forma que aquele que acusa influenciado por esses sentimentos deve ter a possibilidade de renunciar à punição do réu, como uma forma de reparar o mal da acusação puramente vingativa. O perdão da vítima, para Azevedo, é importante para reparação de um possível desvio no sistema processual penal, a acusação vingativa. Mas não apenas por isso.

O autor faz questão de utilizar termos como "clemência", "instintos piedosos da natureza humana”, em uma espécie de relação entre o instituto técnico de direito penal, perdão do ofendido, e o perdão, enquanto ato benéfico de origem cristã. Essa relação, ainda que pouco explorada pelos juristas do período, ajuda a entender a forma como esses autores pensavam esse instituto, não somente pelo seu aspecto técnico, mas também e, por vezes, tal como nesse trecho de Azevedo, sobretudo por esse caráter cristão.

Já no final do século XIX, com a consolidação do que Mafei chama de direito penal contemporâneo, Aurelino Leal ${ }^{35}$, um dos expoentes da Escola Positiva no Brasil, escreve que o perdão do ofendido é um "favor mal" e que a "a Lei não deve ser generosa, nem deve distribuir misericórdia; deve ser sensata e sempre relativa”. Esse autor entende que a valorização moral do perdão, como um ato misericordioso e benéfico, não deve influenciar a avaliação técnica do instituto do perdão do ofendido. “A Lei não deve ser generosa”, por mais que o perdão sob a ótica cristã seja uma atitude positiva, quando se trata de direito penal é um "favor mal”. Essa diferença de pensamento é um reflexo de uma mudança de postura em relação ao perdão do ofendido no final do século XIX, uma

34 AZEVEDO, Manoel Mendes da Cunha. Observações sobre vários artigos do código de processo criminal e outros da lei de 3 de dezembro de 1841, Pernambuco: Typographia da Viuva Roma, 1852, p. 63-64.

35 LEAL, Aurelino. Germens do crime, Bahia: Livraria Magalhães, 1896, p. 182. 
visão mais restrita em relação aos espaços de transação penal e uma preocupação ainda maior com a efetividade das leis penais.

\subsection{O PERDÃO DO OFENDIDO NO CRIME DE OFENSAS FÍSICAS LEVES}

Thomaz Alves Junior ${ }^{36}$ elenca alguns outros critérios para determinar se há ou não possibilidade de acusação oficial nos delitos particulares. O primeiro deles é o art. 37 do Código de Processo Criminal de 1832, que estabelece algumas atribuições dos promotores públicos.

Art. 37. Ao Promotor pertencem as attribuições seguintes:

$1^{\circ}$ Denunciar os crimes publicos, e policiaes, e accusar os delinquentes perante os Jurados, assim como os crimes de reduzir á escravidão pessoas livres, carcere privado, homicidio, ou a tentativa delle, ou ferimentos com as qualificações dos artigos 202, 203, 204 do Codigo Criminal; e roubos, calumnias, e injurias contra o Imperador, e membros da Familia Imperial, contra a Regencia, e cada um de seus membros, contra a Assembléa Geral, e contra cada uma das Camaras. ${ }^{37}$

A primeira parte desse artigo faz referência a já explicada competência dos promotores públicos de denunciar em todos os crimes públicos e policiaes. Porém, o artigo prevê também outros delitos que, de acordo com a classificação do código, são delitos particulares, são eles: escravização de pessoas livres, cárcere privado, homicídio e tentativa dele, além de determinadas qualificações de lesões físicas. Isto é, o que esse artigo faz é delimitar alguns delitos particulares em que é possível a denúncia pelo promotor público, ou seja, é uma das possibilidades de crimes particulares processados por meio de ação penal pública, chamados, portanto, de delitos particulares com acusação oficial, casos nos quais o perdão da vítima não encerra a ação penal.

36 ALVES JUNIOR, Thomaz. Anotações teóricas e práticas ao Código Criminal, Rio de Janeiro: Francisco Luiz Pinto \& C. editores, 1864, p. 660-661.

37 BRASIL. Codigo de processo criminal de primeira instância de 29 de novembro de 1832. Disponível em: <http://www.planalto.gov.br/ccivil_03/leis/LIM/ LIM-29-11-1832.htm> Acesso em: 07/08/2018. 
Apesar dessa aparente clareza do art. 37, Manoel Mendes da Cunha Azevedo ${ }^{38}$, em livro de comentários ao Código de Processo Criminal de 1832, chama a atenção para um problema muito recorrente na prática judiciária, que o autor se propõe a discutir. A redação do art. 37 exclui o delito geral de ofensas físicas, art. $201^{39}$ do Código Criminal, do rol de delitos particulares com acusação oficial, prevendo somente as qualificações dos art. $202^{40}$, art. $203^{41}$ e art. $204^{42}$, fato que levou a maioria dos tribunais do período, de acordo com Azevedo, a tratar o delito do art. 201 como delito particular sem acusação oficial, dependente, portanto, da queixa da vítima para a sua perseguição. Azevedo, porém, discorda dessa postura dos tribunais, e sustenta a sua ideia com base em três argumentos, sendo dois deles de ordem legal e outro, que nos interessa mais, de ordem política-criminal.

Em relação aos dois primeiros, Azevedo argumenta que, meses antes da publicação do Código de Processo Criminal, entrou em vigor a Lei de 26 de outubro de 1831, que estabelece no seu art. 5 que: "Art. $5^{\circ}$ As offensas physicas leves, as injurias, e calumnias não impressas, e as ameaças, reputar-se-hão crimes policiaes, e como taes serão processados." ${ }^{43} \mathrm{O}$ autor argumenta que as offensas physicas leves a que esse artigo faz referência é exatamente o mesmo crime previsto no art. 201

38 AZEVEDO, Manoel Mendes da Cunha. Observações sobre vários artigos do código de processo criminal e outros da lei de 3 de dezembro de 1841, Pernambuco: Typographia da Viuva Roma, 1852, p. 25.

39 "Art. 201. Ferir ou cortar qualquer parte do corpo humano, ou fazer qualquer outra offensa physica, com que se cause dôr ao offendido. Penas - de prisão por um mez a um anno, e multa correspondente á metade do tempo."

40 "Art. 202. Se houver, ou resultar mutilação, ou destruição de algum membro, ou orgão, dotado de um movimento distincto, ou de uma funcção especifica, que se pôde perder, sem perder a vida. Penas - de prisão com trabalho por um a seis annos, e de multa correspondente á metade do tempo."

41 "Art. 203. A mesma pena se imporá no caso, em que houver, ou resultar inhabilitação de membro, ou orgão, sem que comtudo fique destruido."

42 "Art. 204. Quando do ferimento, ou outra offensa physica resultar deformidade. Penas - de prisão com trabalho por um a tres annos, e multa correspondente á metade do tempo."

43 BRASIL. Codigo criminal do Império do Brazil de 16 de dezembro de 1830. Disponível em: <http://www.planalto.gov.br/ccivil_03/Leis/LIM/LIM-16-121830.htm> Acesso em: 07/08/2018. 
do Código Criminal, que havia entrado em vigor um ano antes. Nesse sentido, a previsão do art. 37, que excluiu esse delito, em nada interfere na vigência dessa norma anterior, que prevê as offensas physicas leves como um tipo especial de delito, que deve ser processado como crime policial, isto é, entre aqueles passíveis de denúncia pelo promotor público. Além disso, Azevedo ainda faz referência ao aviso imperial de 30 de julho de $1844^{44}$, que reafirma a vigência da Lei de 26 de outubro de 1831, mesmo após a entrada em vigor do Código de Processo Criminal de 1832. Porém, apesar desses argumentos e dessas disposições legais, Azevedo afirma que os tribunais, de forma geral, adotam uma postura inexplicável, não admitindo a denúncia pública nessa classe de delitos, promovendo, assim, a impunidade.

Nesse ponto, o autor utiliza-se do seu outro argumento, de natureza política, para defender a possibilidade de denúncia pública no delito previsto no art. 201:

Quanto ao fundamento juridico desta sabia providencia, basta reflectir, que estes são os crimes, a que dão materia as paixões mais frequentes, e os interesses mais disputados do homem nas situações mais ordinarias da vida, d'onde muitas vezes se tem seguido os delictos mais horrorosos, e que mais facilmente perturbão a paz, e a segurança individual dos Cidadãos, dignos por consequencia de serem prevenidos pelas leis repressivas em toda estensão das attribuições policiaes, que o $\$ .5^{\circ}$ prescreve para os crimes, que são muitas vezes a sua causa immediata, ou predisponente. Em vez de os corrigir, a impunidade lhes hiria dar vigor, animando a causa occasional de outros, que ellas punem com penas mais severas. Por esta razão não devêra a repressão dos crimes, por assim dizer, occasionaes ficar ao arbitrio do queixoso, que os poderia accusar,

44 “ $[. .$.$] Houve o Mesmo Augusto Senhor por bem, Conformando-se com o pa-$ recer do Conselheiro d' Estado, Procurador da Coroa, e Soberania Nacional, mandar declarar a V. Ex., para que o faça constar ao referido Juiz, o seguinte: $1^{\circ}$, que a Lei de 26 de Outubro de 1831, sendo hum verdadeiro additamento ao Codigo Criminal, ainda não foi revogada nas suas disposições penaes (...) $2^{\circ}$, que as offensas physicas leves de que trata o Artigo $5^{\circ}$ da referida Lei de 26 de Outubro de 1831, se poderão bem classificar, quando for preciso para a imposição das penas, sob as disposições do Artigo 201, na segunda parte, e do Artigo 206 do Codigo Criminal.” BRASIL. Aviso de 30 de julho de 1844 . In: Collecção das decisões do governo do império do Brasil, v. VII, 1844. 
ou deixar de accusar, como melhor lhe parecesse, por indulgencia, ou malicioso projecto de lhes oppôr os excessos da vindicta privada. Cumpria pois que o Promotor publico fosse legalmente encarregado de os denunciar, e promover a sua accusação. ${ }^{45}$

Aqui, o argumento de Azevedo funda-se na necessidade de repressão estatal em relação a delitos muito comuns e que "facilmente perturbão a paz, e a segurança individual dos Cidadãos". Nesse trecho, o autor sustenta que a função da pena e, portanto, a necessidade da punição é fundada não na restituição do mal cometido a um indivíduo, visto que esse delito (art. 201) é, dentre aqueles previstos no código, um dos com menor potencial lesivo, mas na necessidade de desencorajar outros potenciais criminosos a praticá-lo. A penalização fundada na ideia de prevenção geral é o argumento principal para a negativa do autor em permitir que esse delito seja classificado dentre aqueles que dependem de queixa da vítima para o início do processo penal. Se a pena não é fundada na retribuição do dano, e sim no desincentivo à prática de novos delitos, não há espaço para a clemência privada no pensamento de Azevedo, visto que, por mais que não haja mais um desejo de vingança por parte do ofendido, a sociedade ainda reclama por proteção.

E, confirmando a preocupação de Azevedo com esse delito, foi possível extrair algumas informações dos principais periódicos do país nesse período. A pesquisa foi feita através da Hemeroteca Digital e a metodologia foi a seguinte: a busca foi feita através da palavra chave "ofensas physicas leves" em todos os jornais disponíveis online referentes ao período pesquisado, dentre eles destaco a Gazeta dos Tribunaes, o Correio Oficial e o Diário do Rio de Janeiro. Além disso, a pesquisa foi dividida em três períodos, 1830-1839, 1840-1849 e 1850-1859. Como os resultados encontrados não foram tão extensos, foi possível analisar cada um individualmente, retirando os dados eventualmente duplicados.

De forma geral, foi possível extrair algumas conclusões. Houve um aumento no número de referências a esse crime nos jornais a partir da década de 1850 em comparação com a década de 1830 e 1840. Enquanto

45 AZEVEDO, Manoel Mendes da Cunha. Observações sobre vários artigos do código de processo criminal e outros da lei de 3 de dezembro de 1841, Pernambuco: Typographia da Viuva Roma, 1852, p. 29-30. 
nas duas primeiras décadas de vigência do Código de 1830, encontramos, somadas, quinze referências à prática desse delito (cinco na década de 1830 e dez na década de 1840), esse número aumenta para trinta e um na década de 1850, período no qual Azevedo escreveu sobre a necessidade de punição das “ofensas physicas”. Mas não é somente isso. Há uma grande diferença na forma de acusação desse delito. Dos cinco casos encontrados na década de 1830, todos foram acusados por particular, geralmente o ofendido fisicamente, mas esse cenário se altera nas décadas seguintes, visto que no período de 1840-1849, dos dez casos encontrados, cinco foram acusados pelo promotor público e quatro por particulares (um desses casos não tem referência à acusação), enquanto, na década seguinte, das trinta e uma referências, vinte e cinco eram acusações pela Justiça Pública, e apenas cinco foram movidas por particulares (novamente um caso não tinha referência à acusação).

Outro dado interessante diz respeito ao número de condenações. Na década de 1830, dos casos que apareceram nos jornais, nenhum réu foi condenado, quatro foram absolvidos, sendo que desses quatro, dois foram perdoados pela vítima e um outro não aparece informação sobre o resultado do processo. No entanto, mesmo nesse em que faltam informações, há um pequeno trecho no qual reclamava-se sobre a falta de novidades no processo, que provavelmente foi paralisado devido à inatividade da vítima na acusação. Na década seguinte, esse quadro de falta de condenações não se altera muito, de forma que foi encontrada somente uma condenação, quatro absolvições e outros cinco processos sem informações sobre o resultado. No período de 1850-1859, aumenta o número de condenações (nove em trinte e um casos), porém a quantidade de absolvições (vinte dos trinte e um) ainda é muito superior.

Dessa forma, podemos chegar a algumas conclusões: a) é evidente que não podemos desconsiderar uma possível mudança de perfil das revistas ${ }^{46}$, com o aumento do número de relatos de decisões, mas ainda assim, esse aumento tão grande certamente não pode ficar à cargo

46 Sobre o tema destaco: SILVEIRA, Mariana de Moraes. Revistas jurídicas brasileiras: "cartografia histórica" de um gênero de impressos (anos 1840 a 1940). Caderno de Informação Jurídica, Brasília, v. 1, n. 1, p. 98-114, 2014. 
apenas disso, de forma que, certamente, houve, pelo menos, uma maior repercussão desses crimes, o que explica a afirmação de Azevedo de que são delitos que estão incomodando a paz e a segurança individual; b) a partir da década de 1840, há um maior interesse da justiça pública por esses casos, de forma que mais da metade dos casos foram acusados pelo promotor público, mas apenas no final da década de 1850 a acusação pública se torna regra nesse tipo de delito, com o que podemos levantar a hipótese de que, apesar da publicação da lei de 26 de outubro de 1831, a aplicação do art. 5 sobre a possibilidade de denúncia dos crimes de ofensa pública leve pelo promotor público talvez não tenha sido aplicada, ao menos até a década de 1850; c) o aumento do número de condenações caminha conjuntamente com o movimento de acusação pública desse delito.

Disso é possível perceber como a negação do perdão do ofendido, tal como defendido por Azevedo, provavelmente se alinha ao aumento de eficácia e controle da impunidade a determinados delitos, especialmente àqueles mais leves, como a agressão física. Dessa forma, parece claro que a acusação pública e, portanto, a exclusão da interferência privada, através do perdão, do processo penal, caminha paralelamente com o aumento do número de condenações.

\subsection{A POLÊMICA QUESTÃO DO PERDÃO DO OFENDIDO MISERÁVEL}

Além das previsões de denúncia pública do art. 74 e do art. 37, ambos do Código de Processo Criminal de 1832, há outra possibilidade de denúncia pelo promotor público, o art. 73 do mesmo código: "Art. 73. Sendo o offendido pessoa miseravel, que pelas circumstancias, em que se achar, não possa perseguir o offensor, o Promotor Publico deve, ou qualquer do povo pôde intentar a queixa, e proseguir nos termos ulteriores do processo." ${ }^{77} \mathrm{O}$ que esse artigo faz é atribuir ao promotor público a possibilidade de denunciar o crime cometido contra ofendido miserável, independente da natureza do delito, particular com acusação oficial ou

47 BRASIL. Codigo de processo criminal de primeira instância de 29 de novembro de 1832. Disponível em: <http://www.planalto.gov.br/ccivil_03/leis/LIM/ LIM-29-11-1832.htm> Acesso em: 07/08/2018. 
sem acusação oficial. Vicente Alves de Paula Pessoa ${ }^{48}$ enxerga nisso uma espécie de assistência judiciária e afirma que o miserável é aquele que não tem condições materiais de perseguir o ofensor em juízo, de forma que se exige a atuação pública para a acusação.

A dúvida suscitada por esse dispositivo, e que será bastante discutida nesse período, diz respeito à possibilidade de o ofendido miserável perdoar o ofensor e desistir do processo, mesmo após a acusação pública.

Manoel Mendes da Cunha Azevedo é um dos primeiros autores a discutir sobre o tema, sendo a sua opinião a mais citada entre os outros juristas do período, tal como Pessoa e Barroso. Escreve Azevedo que:

Nos termos da lei a competencia do Promotor para accusar as offensas feitas ás pessoas, em quem concorrão as circumstancias mencionadas neste artigo, he absoluta, e independente da vontade do offendido; porque a lei não diz: não accusando, ou não querendo accusar a pessoa miseravel, como no caso flagrante do $\$ .6$ do art. 74: não havendo parte que o accuse; antes pelo contrario o art. 73 incumbe imperativamente ao Promotor a effectividade da denuncia - O Promotor deve - ; logo huma deliberação contradictoria com as disposições reguladoras da materia não pôde prevalecer para dispensar o Promotor da accusação, ainda que razoavel fosse. Na razão da lei o oficio do Promotor he reclamado por huma necessidade geralmente sentida. ${ }^{49}$

O autor é contrário a que o perdão do ofendido miserável ponha fim ao processo acusado pelo promotor público e a primeira parte do seu argumento diz respeito à literalidade da norma. Diferente da situação do flagrante, explicada no item anterior, em que Azevedo entende que a acusação pública na situação ocorre somente nas situações em que não há acusação privada, no caso de miserabilidade a lei exige a denúncia

48 PESSOA, Vicente Alves de Paula. Codigo criminal do imperio do Brazil: annotado com leis, decretos, jurisprudencia dos tribunaes do paiz e avisos do governo até o fim de 1876: contém além disso muita materia de doutrina, com esclarecimentos e um indice alfabético, Rio de Janeiro: Typografia Perseverança, 1877, p. 135.

49 AZEVEDO, Manoel Mendes da Cunha. Observações sobre vários artigos do código de processo criminal e outros da lei de 3 de dezembro de 1841, Pernambuco: Typographia da Viuva Roma, 1852, p. 54-55. 
pelo promotor público, sendo essa independente e absoluta em relação à vontade das partes.

O autor completa ainda que essa garantia tem origem em uma necessidade geral da sociedade de proteger os seus membros mais frágeis que, por motivos diversos, reclamam a vigilância e os socorros da autoridade pública. Azevedo faz então uma importante analogia, que ajuda a entender a lógica do seu pensamento. Afirma o autor que, assim como o pai realizar a queixa em uma situação de crime puramente particular perdoado pelo filho, visto que a família também é vítima desse tipo de delito, a sociedade também pode acusar quando o ofendido miserável perdoa. No primeiro caso, por que a família ofendida, direta ou indiretamente, pelo crime, como na situação do delito de injúria ou calúnia, e no segundo caso pelo fato de que a sociedade também sofre consequência pelo cometimento de um delito contra um dos seus membros mais fracos, o miserável.

Azevedo vai além e afirma que um crime cometido contra um miserável não só não pode ficar impune, mesmo se aquele que sofreu diretamente as ofensas assim o desejar, mas deve ser mais fortemente punido, visto que:

A offensa feita a huma pessoa miseral he tanto mais aggravante da justiça, e da tranquillidade publica, quanto ella revela da parte do offensor huma disposição mais perigosa para o mal. He barbara; porque offende a hum infeliz, que tem direito á commiseração de todos: he atroz; porque aggrava a situação daquelle, a quem a sorte já condemnou á miseria: he insidiosa; porque acommette hum desgraçado, que de ninguem podendo esperar, senão soccorros, e consolação, não pôde prevenir os meios de a evitar: he finalmente covarde; porque fere a hum individuo, cuja fraqueza não pôde repellir o golpe. O concurso destas circumstancias tornão o offensor hum homem execravel, e recommendão hum castigo exemplar. ${ }^{50}$

$\mathrm{O}$ autor entende que aqueles que cometem delitos nesse sentido são mais perigosos para a ordem social, de forma que a sua punição não

50 AZEVEDO, Manoel Mendes da Cunha. Observações sobre vários artigos do código de processo criminal e outros da lei de 3 de dezembro de 1841, Pernambuco: Typographia da Viuva Roma, 1852, p. 56. 
pode ficar sob o arbítrio da parte ofendida, já que a sociedade é também interessada na devida correção desse tipo de desvio. O argumento utilizado aqui é muito próximo daquele empregado pelo mesmo autor na situação da denúncia das ofensas físicas leves: o da necessidade da eficácia da punição pelo exemplo, para evitar a propagação desse tipo de delito. A negativa do perdão para Azevedo é, então, uma forma de a sociedade se defender nesses dois sentidos, tanto por ser uma forma de reparar o mal cometido pelo crime, visto que ela é também ofendida, em uma visão retributivista da pena, quanto uma maneira de a sociedade se proteger do possível perigoso inimigo, em uma lógica de prevenção.

Mas, nem todos pensavam como Azevedo. Diferente da grande maioria dos autores do período, que escreviam livros de comentários aos artigos do Código Criminal e do Código de Processo Criminal, Liberato Barroso escreve as "Questões práticas de direito criminal”, um livro em que ele discute dez importantes temas para os advogados do período. Apesar de um modelo bastante diferente daquele geralmente adotado pelos juristas na época, o livro de Barroso era também destinado aos advogados e juízes, à prática criminal, como ele faz questão de deixar claro na introdução, em que afirma a preocupação em dar a sua interpretação para essas questões, como uma forma de auxiliar na aplicação das leis. A questão terceira era a seguinte: "Quaes os effeitos do perdão do offendido nos casos, em que o Promotor Publico accusa por ser aquelle pessoa miserável?" A dúvida aqui é a mesma discutida por Azevedo, isto é, sobre a possibilidade de o ofendido miserável perdoar o réu, eximindo-o das penas, na situação de acusação pelo promotor público. Mas a resposta dada por Barroso é bastante diferente daquela proposta por Azevedo.

Barroso explica que o propósito do art. 73 do Código de Processo Criminal de 1832 é oferecer uma proteção maior àqueles que não possuem meios suficientes para promover a acusação, de forma que qualquer do povo, através da ação popular, ou o promotor público, através da ação pública, acusem o ofensor e impeçam a impunidade do delito. Porém, eis o argumento principal apresentado pelo autor, esse dever da acusação pública, previsto na legislação, não altera a natureza do delito, isto é, o seu caráter privado, não mudando também, consequentemente, a natureza da ação derivada dele. Explica Barroso que: 
Estabelecendo a acção privada, como meio exclusivo de perseguir em juizo uma certa classe de crimes, não quiz o legislador deixar sem proteção aquelles, que pela sua miséria não podem accusar os offensores: consagrou o auxilio de qualquer pessoa do povo, dando-lhe o direito de promover a accusação; e prescreveu ao Promotor Publico o dever de prestar este auxilio. Mudou porem a natureza da acção? A acção privada, que compete ao offendido pelos crimes, em que não tem lugar o procedimento official, assume o caracter de acção publica, quando a queixa é intentada pelo Promotor Publico ou por qualquer pessoa do povo? Muda também de natureza o delicto; e torna-se a sua punição uma necessidade de ordem social, independente da vontade do offendido, só porque este é pessoa miserável? Parece-nos, que a negativa não pôde soffrer a menor hesitação. ${ }^{51}$

O autor defende que a natureza do crime e, portanto, da ação penal, é derivada, em última análise, da importância e gravidade dos delitos, e isso não se altera pela situação de miserabilidade do ofendido. De acordo com Azevedo, a atuação do promotor público na situação de miserabilidade é fundada em um sentimento social de defender os mais fracos, através da perseguição e punição do delito cometido. Para Barroso, a intervenção da Justiça Pública nessas circunstâncias não se dá por uma necessidade de ordem pública, é somente um benefício concedido ao ofendido, em uma lógica de assistência judiciária, mas que não muda a natureza do delito inicialmente cometido.

Barroso destaca também que o art. 73 refere-se à queixa do Promotor Público, não denúncia, instrumento típico da ação penal pública: "Art. 73. Sendo o offendido pessoa miseravel, que pelas circumstancias, em que se achar, não possa perseguir o offensor, o Promotor Publico deve, ou qualquer do povo pôde intentar a queixa, e proseguir nos termos ulteriores do processo." ${ }^{52}$ Para o autor não se trata de um erro do legislador, mas uma disposição pensada, com a intenção de

51 BARROSO, José Liberato. Questões práticas de direito criminal, Rio de Janeiro: B. L. Garnier, 1866, p. 41.

52 BRASIL. Codigo de processo criminal de primeira instância de 29 de novembro de 1832. Disponível em: <http://www.planalto.gov.br/ccivil_03/leis/LIM/ LIM-29-11-1832.htm> Acesso em: 07/08/2018. 
demonstrar que a natureza do delito e da ação penal não se altera com a miserabilidade da parte ofendida.

Barroso ainda utiliza um terceiro argumento para defender a possibilidade de perdão do ofendido miserável, a situação de acusação puramente vingativa. $\mathrm{O}$ autor afirma que o art. 73 possibilita também a ação popular, isto é, a possibilidade de denúncia por qualquer do povo, de forma que um terceiro, mesmo que não envolvido diretamente no delito, denuncie e acuse o réu. $\mathrm{O}$ autor afirma que a permissão concedida através da ação popular de denúncia e acusação de terceiros não envolvidos no delito penal é forma de permitir-se uma acusação com desejos puramente vingativos, em que a vítima não deseja a reparação e a sociedade não a pode exigir, visto a natureza do delito. O perdão do ofendido é, então, uma maneira de corrigir essa falha do sistema, afinal, a vítima miserável, por mais que não seja parte acusadora no processo, pode encerrá-lo através do instrumento do art. 67.

\section{O Código Penal de 1890 e o perdão do ofendido: "UM PRODUTO ANACHRONICO DE IDÉAS METAPHYSICAS"}

Durante a vigência do Código Criminal de 1830 o perdão do ofendido tinha um tratamento bastante bipolar, tal como visto nas páginas anteriores. Havia juristas, como Manuel Mendes da Cunha Azevedo, que o criticavam e defendiam o aumento do número de acusações públicas no âmbito penal, e outros, como Barroso, que ainda enxergavam a sua importância na correção de falhas do sistema e em determinados delitos com características privadas. Apesar dessas posições diferentes, é interessante observar como a presença e a relativa centralidade do perdão nos debates penais no Brasil oitocentista representam um traço da estratégia do poder público no que diz respeito às questões de transação penal no século XIX, uma clara tentativa de internalizar as práticas de negociação, de controla-las, manejando-as de acordo com o interesse público. ${ }^{53}$

53 O que não quer dizer que práticas extrajudiciais não sejam comuns no Brasil desse período. Não são poucas as referências a isso, seja na literatura, com, por exemplo, a peça teatral "O juiz de paz na roça”, escrita por Martins Pena na década de 1830, ou ainda em estudos científicos como os feitos por 
Com a aprovação do Código Penal de 1890, é facilmente perceptível uma postura mais rígida em relação às práticas de transação, aqui analisadas pela figura do perdão do ofendido. O que até esse período poderia ser interpretado como uma estratégia de internalização, a partir de então se mostra como uma postura muito mais agressiva dos legisladores e juristas frente a essas práticas. Como exemplo do que estamos querendo demonstrar, escolhemos dois juristas, Aurelino Leal e Viveiros de Castro, para uma pequena análise de como o instituto do perdão se modifica ao longo do século e de como essas mudanças são reflexos de uma alteração de ordem mais geral.

Antes, porém, de tratar desses dois autores, convém fazermos uma pequena análise das importantes mudanças legislativas em torno do perdão do ofendido. Diferente do Código Criminal de 1830 que condicionava esse instituto aos requisitos explicados anteriormente, o Código Penal de 1890 mudou completamente esse panorama, simplificando-o. Em se tratando das ações penais, a ação penal popular deixou de existir, de forma que apenas duas classes se mantivessem, a ação penal privada e a ação penal pública. Nesse sentido, o art. 407 do novo código disciplina que o promotor público deve denunciar, dando lugar a ação penal pública, em todos os crimes previstos no código, com exceção em duas hipóteses, nos crimes de furto ${ }^{54}$ e dano, quando há flagrante delito e nos crimes de violência carnal, rapto, adultério, parto suposto, calúnia e injúria, esses seis últimos exclusivamente privados. ${ }^{55}$

Thomas Flory, "El juez de paz y el jurado en el Brasil imperial”, 1986, Ivan de Andrade Vellasco, "As seduções da ordem: violência, criminalidade e administração da justiça: Minas Gerais - século 19.”, 2004, ou ainda em um período um pouco posterior, João Paulo Mansur, em sua dissertação de mestrado, "Aos amigos o direito; aos inimigos a lei: modernismo, coronelismo, júri e cangaço na literatura de José Lins do Rego, 2017”.

54 A situação do furto é mais complexa. Apesar da previsão genérica do código acerca da exclusividade da ação penal privada, com exceção nos casos de flagrante delito, ao longo do século XIX com a organização dos códigos de processo penal estaduais, um grande número de estados optou por alterar a ação penal do crime de furto, tornando-a pública. Além disso, há também a situação específica do furto de gado, sobre a qual ressalto o seguinte estudo: LOURENÇO, Lucas Ribeiro Garro. Furto de gado e justiça não estatal: sobre o nascimento da ação penal pública condicionada à representação no Brasil (1860-1899). No prelo.

55 No caso do delito de violência carnal, o art. 274 do Código Penal de 1890 abre três algumas à regra da acusação privada, nas situações em que haja perigo 
Isso reflete diretamente no perdão do ofendido, visto que o art. 77, dispositivo que regula esse instituto no código de 1890, prevê que o perdão do ofendido só terá efeitos jurídicos, extinguindo a ação penal ou a execução da sentença, nos delitos em que haja acusação pelo ofendido, isto é, nos casos em que só terá lugar a ação penal privada.

O que fica evidente, desde já, é uma tentativa de restringir o espaço do perdão do ofendido, com a inversão da lógica da acusação no processo penal. Enquanto, na legislação imperial, a regra era a acusação privada em todos os crimes particulares, parte terceira do Código de 1830, com as devidas exceções em que havia acusação pública pelo promotor (art. 37, art. 73 e art. 74, do Código de Processo Criminal de 1832), no nosso primeiro código penal republicano a regra passa a ser a de acusação pública para todos os delitos, com apenas oito exceções, em que há exclusividade da ação penal privada: furto, dano, violência carnal, rapto, parto suposto, adultério, calúnia e injúria.

Essa grande mudança legislativa é acompanhada também de uma mudança de postura sobre o perdão do ofendido na doutrina jurídica, exemplificadas aqui com os já citados Aurelino Leal e Viveiros de Castro, dois dos autores mais críticos em relação a esse instituto. Leal publica o livro "Gérmens do Crime" seis anos após a promulgação do código penal republicano. Um livro que, como define o autor, tem por objetivo combater determinados institutos de direito material e processual penal adotados por legisladores "não iluminados". O que o autor chama de gérmens do crime são, portanto, institutos considerados atrasados e, sobretudo, auxílios da criminalidade, ou como o próprio autor os define: "espessas capas em que se embuçam os malfeitores para fugirem da punição legal". ${ }^{56}$

O perdão do ofendido é, portanto, na concepção de Leal, um desses gérmens, um incentivo à criminalidade. A sua explicação merece ser replicada:

de vida, morte ou grave alteração da saúde da ofendida, quando a ofendida for pessoa miserável ou, ainda, quando o crime for cometido com abuso de pátrio poder, autoridade do tutor, curador ou preceptor. Nessas hipóteses, a acusação poderia ser feita pelo Ministério Público.

56 LEAL, Aurelino. Germens do crime, Bahia: Livraria Magalhães, 1896, p. 18 
A Lei diz, por exemplo, que é crime matar-se alguem. A escola penal estuda e dá toda a consideração á intenção criminosa. Pois bem. A resolução do crime uma vez provada, equivale a manifestação clara de que o individuo quer violar uma Lei. E, desde que elle armado dirige- se á sua victima, quem é o primeiro a ser lesado? ${ }^{57}$

A sociedade é, nessa visão, a vítima primeira do crime e contra o autor tem o direito de se mover. Completa Leal que:

Na consideração, portanto, de que a repressão é da exclusiva competencia da sociedade, e que só póde exercer esse direito o individuo para defender-se legitimamente contra os seus aggressores ou de terceiros, por medida de excepção, não podemos concordar com esta disposição da Lei, que concorre secundariamente para o enfraquecimento da repressão criminal [...]. O Art. 77 do Coligo Penal Brazileiro (artigo que regula o perdão do ofendido no Còdigo Penal de 1890) dispoz isto, mas é uma disposição que não merece ser commentada. ${ }^{58}$

Poucas páginas depois, Leal escreve que:

Quanto ao perdão, é que não ha razão, em absoluto, para existir. $\mathrm{O}$ individuo não póde ter a larga attribuição de perdoar a offensa que recebeu. Existindo a graça com as modificações que estabelecemos não ha necessidade nenhuma de existir o perdão, que é um produto anachronico de idéas metaphysicas. Elimene-se-o do direito positivo, pois. ${ }^{59}$

Viveiros de Castro, um dos mais importantes juristas brasileiros do século XIX e primeira metade do XX, em especial no que se refere aos crimes sexuais, é outro a tratar do tema. A obra dele pode ser sintetizada em três principais livros: a "Nova Escola Penal" ( $\left.1^{\mathrm{a}} \mathrm{ed}, 1894\right)$, "Atentados ao Pudor" (1895) e "Delictos contra a Honra da Mulher" ( $1^{\mathrm{a}}$ ed, 1897). Tanto no primeiro quanto no último desses livros, o autor discute o perdão da vítima e, principalmente, a divisão entre ação penal pública e privada.

\footnotetext{
57 LEAL, Aurelino. Germens do crime, Bahia: Livraria Magalhães, 1896, p. 180-181 
Convém concentrarmos nos argumentos referentes à questão das ações, no qual Castro desenvolve melhor seu pensamento.

Em “A Nova Escola Penal”, o autor pretende instituir as bases da sua teoria, como ele mesmo define, bastante antenada com o que se escrevia no período na França e na Itália, no campo da antropologia criminal e da sociologia criminal. Nesse sentido, esse livro é, de acordo com Castro, um resumo das ideias dos principais expoentes dessas escolas, adaptados à realidade brasileira. Um desses pontos centrais diz respeito à clássica divisão, adotada pela legislação brasileira, entre ação penal pública e privada, da qual o autor discorda:

Instituindo o ministério publico, o fim da lei foi dar á sociedade um representante que zelasse pelos seus direitos, mas calmo, frio, imparcial, sem ódios e sem paixões, inflexível, severo no cumprimento de seus deveres. A pena na moderna concepção jurídica deste século não é mais uma vingança do offendido, mas urna necessidade de defeza social. A lesão ao direito individual é também uma lesão ao direito collectivo. Não deve, portanto, caber ao particular a reparação dessa offensa; mas sim ao promotor publico, que falla em nome dos interesses sociaes. Deixar ao particular o direito de queixa, de punir ao seu aggressor, é dar logar a duas conseqüências bem perigosas, offensiva uma do direito individual, outra do interesse social. Offensiva do direito individual porque se cada cidadão pôde por uma queixa iniciar um processo contra outro, comprehende-se quantas vinganças, quantas especulações, quanta chantage, não podem ser exercidas á sombra deste direito de queixa. [...] Offensiva do direito social, porque se a victima não quizer procurar seu aggressor, fica impune um indivíduo perigoso, animado por essa mesma impunidade a commetter novos crimes. O ladrão continua a furtar, o seductor a deshonrar moças, o calumniador a manchar reputações imaculadas. Não, mil vezes não. É tempo de abandonar semelhante systema desacreditado e seguir o caminho mais seguro que nos ensina a nova escola penal. Não ha motivo que justifique a divisão da acção penal em publica e privada. A iniciativa do processo deve sempre caber ao representante do ministério publico. ${ }^{60}$

60 CASTRO. Francisco José Viveiros de. A nova escola penal, Rio de Janeiro: J.R. dos Santos, 1913., p. 261-263. 
No livro "Delictos contra a Honra da Mulher", Castro retoma essa ideia e escreve sobre as ações penais nos delitos de adultério, violência carnal e rapto. Apesar da tendência da época em considerar esses tipos de delitos como essencialmente privados, lembremos que eles estão entre aqueles em que a acusação é exclusivamente privada (art. 74 do Código Penal de 1890) ${ }^{61}$, Viveiros de Castro mantém sua posição contrária à ação penal privada, rechaçando o que ele chama de quatro argumentos básicos daqueles que defendem a posição contrária, isto é, defensores da exclusividade da acusação privada em determinados crimes: 1) a preservação do interesse familiar e da privacidade da vítima; 2) dificuldade no colhimento de provas; 3 ) correção de possíveis injustiças na condenação através do perdão do ofendido; 4) recurso contra a inação do Ministério Público. ${ }^{62}$

Para nós, interessa mais o terceiro ponto, em que Castro não reconhece no perdão a única válvula de escape para o reconhecimento de possíveis erros na condenação nesses tipos de crimes. Para o autor, há outros instrumentos possíveis e mais viáveis, tais como o direito de graça e o recurso de revisão ao Superior Tribunal de Justiça, ambos criados com esse intuito de reconhecer possíveis injustiças e corrigi-las, mas que não comprometeriam a paz social e nem favoreceriam a impunidade, fatores característicos do perdão do ofendido.

Essa concepção de delito como algo público e da necessidade de repressão para evitar a propagação da criminalidade, expressos nos escritos anteriores, não é algo exatamente novo na doutrina jurídico-penal brasileira, como visto anteriormente com o pensamento de Azevedo na década de 1850 . Porém, chama a atenção a intensidade como isso se coloca no final do século XIX. Se durante o Império reclamava-se sobre a necessidade de acusação pública em delitos menores, como as lesões físicas

61 Vale citar que no Código Penal de 1940 manteve-se a ação penal privada, conforme art. 225 desse dispositivo, sendo prevista ainda duas hipóteses em que há ação pública incondicionada, incisos I e II do mesmo artigo. Em 2009, através da Lei n. 12.015 foi acrescentado previsão de ação pública condicionada e de mais uma hipótese de ação pública incondicionada. Apenas através da Lei n. 13.718/2018 o art. 225 foi amplamente modificado, sendo previsto ação pública incondicionada para todos os crimes contra a dignidade sexual.

62 CASTRO, Francisco José Viveiros de. Os delictos contra a honra da mulher: adultério, defloramento, estupro, a seducção no direito civil, Rio de Janeiro: João Lopes da Cunha, 1897, p. 183. 
leves e de como isso seria importante para a repressão desses delitos, no final do século, mesmo com as intensas mudanças legislativas e a feroz restrição ao perdão do ofendido no código de 1890, a doutrina jurídica ainda demanda mais repressão, dessa vez com a proposta de exclusão do perdão da legislação penal e do monopólio da ação penal pública.

\section{Considerações Finais}

Um instituto jurídico passa por diversas transformações ao longo da história, algumas muito claras e óbvias e outras que exigem um olhar mais apurado do investigador. A proposta desse artigo era analisar as transformações que o perdão do ofendido passou ao longo do século XIX no Brasil, sob o ponto de vista legislativo, teórico e, eventualmente, prático e os resultados se mostraram condizentes com outras pesquisas histórico-científicas paralelas. Tal como escreve, Tomas y Valiente ${ }^{63}$, era de se esperar que o perdão da vítima sofresse alterações significativas no seu modo de funcionamento no século XIX, devido aos códigos penais e seu caráter centralizador, e isso foi de fato verificado, se comparado com os resultados da própria pesquisa do historiador do direito espanhol.

Mafei ${ }^{64}$ escreve como a consolidação do que ele chama de Direito Penal Contemporâneo no Brasil, ocorre apenas no final do século XIX, sobretudo na década de 1890, na qual os três macrotemas básicos, eficiência da punição, centralização política do poder criminal e controle de arbitrariedades, se solidificam como pilares desse modo de se fazer justiça penal no país. Nesse mesmo período, observamos uma substancial diferença legislativa e teórica no instituto do perdão do ofendido, com o aumento das críticas e afirmações sobre a necessidade de se excluir esse elemento da legislação nacional.

63 TOMAS Y VALIENTE, Francisco. El perdón de la parte ofendida en el Derecho penal castellano (siglos XVI, XVII y XVIII). In: Anuario de historia del derecho español, n. 31, 1961, p. 94. brasileiros do século XIX: a construção do direito penal contemporâneo na obra de P. J. A. Feuerbach e sua consolidação entre os penalistas no Brasil. Tese (Doutorado em Direito) - Faculdade de Direito da Universidade de São Paulo, São Paulo, 2008, p. 248. 
Durante a vigência do Código Criminal de 1830, o perdão da vítima era uma resposta possível somente aos crimes particulares sem acusação oficial que não se enquadrassem nas hipóteses do art. 74 do Código de Processo Criminal. Além disso, era possível que o perdão ocorresse antes ou depois da sentença condenatória, o que significa dizer que mesmo após o início do cumprimento da pena era possível que a vítima encerrasse o poder punitivo estatal.

O que pode parecer, à principio, uma ampla fonte de interferência privada no processo penal, pode ser entendido, na verdade, como o contrário. Pelos estudos de Tomas y Valiente vê-se que o perdão da vítima até o final do século XVIII era amplamente negociado, com pouco e difícil controle estatal. O que se propõe aqui é mostrar essa primeira fase, a partir do Código Criminal de 1830 como um momento de internalização, de controle por parte do Estado dessas práticas de negociação.

Em um segundo momento, marcado pelo Código Penal de 1890, a estratégia é diferente. Restringe-se o perdão da vítima a somente oito crimes, enquanto que todos os demais agora passam a ser de competência pública. Essa mudança tão drástica não pode ser resultado de simples vontade legislativa, mas parte desse percurso teórico do direito processual penal ao longo do século XIX no Brasil, um caminho em que os macrotemas básicos, definidos por Mafei, são os guias principais.

Importa perceber aqui, por fim, como o perdão do ofendido foi perdendo relevância ao longo do século XIX, a ponto de na década de 1890 a sua simples previsão na legislação ser alvo de críticas pelos principais juristas do período, e de como isso reflete uma mudança maior, de maior presença estatal nas questões criminais e do pouco espaço dado às soluções negociadas.

\section{RefERÊNCIAS BibLIOGRÁFICAS}

ALVES JUNIOR, Thomaz. Anotações teóricas e práticas ao Código Criminal, Rio de Janeiro: Francisco Luiz Pinto \& C. editores, 1864.

AZEVEDO, Manoel Mendes da Cunha. Observações sobre vários artigos do código de processo criminal e outros da lei de 3 de dezembro de 1841, Pernambuco: Typographia da Viuva Roma, 1852. 
BARROSO, José Liberato. Questões práticas de direito criminal, Rio de Janeiro: B. L. Garnier, 1866.

BECCARIA, Cesare. Dos delitos e das penas, São Paulo: Martin Claret, 2014.

CASTRO, Francisco José Viveiros de. Os delictos contra a honra da mulher: adultério, defloramento, estupro, a seducção no direito civil, Rio de Janeiro: João Lopes da Cunha, 1897.

CASTRO, Francisco José Viveiros de. A nova escola penal, Rio de Janeiro: J.R. dos Santos, 1913.

DANTAS, Monica Duarte. Da Luisiana para o Brasil: Edward Livingston e o primeiro movimento codificador no Império (o Código Criminal de 1830 e o Código de Processo Criminal de 1832). In: Jahrbuch fur Geschichte Lateinamerikas (1998) / Anuario de Historia de América Latina, v. 52, 2015, p. 117-205.

HESPANHA, Antônio Manuel. Cultura jurídica europeia: síntese de um milênio, Coimbra, 2012.

HOSTETTLER, John. A history of Criminal Justice in England and Wales, UK: Waterside Press, 2009.

LEAL, Aurelino. Germens do crime, Salvador: Livraria Magalhães, 1896.

MECCARELLI, Massimo. Regimes jurídicos de exceção e sistema penal: mudanças de paradigma entre Idade Moderna e Contemporânea. In: DAL RI JÚNIOR, Arno; SONTAG, Ricardo. História do direito penal entre medievo e modernidade. Belo Horizonte: Del Rey, 2011, p. 87-110.

MONTENEGRO, Manoel Januário Bezerra. Lições acadêmicas sobre artigos do codigo criminal, Recife: Typographia Universal, 1860.

PADOA-SCHIOPPA, Antonio. Delitto e pace privata. In: PADOA-SCHIOPPA, Antonio. Italia ed Europa nella storia del diritto, Bologna: Il Mulino, 2008. p. 209-229.

PESSOA, Vicente Alves de Paula. Codigo criminal do imperio do Brazil: annotado com leis, decretos, jurisprudencia dos tribunaes do paiz e avisos do governo até o fim de 1876: contém além disso muita materia de doutrina, com esclarecimentos e um indice alfabético, Rio de Janeiro: Typografia Perseverança, 1877.

PIMENTA BUENO, José Antônio. Apontamentos sobre o processo criminal, Rio de Janeiro: Empreza Nacional do Diario, 1857.

QUEIROZ, Rafael Mafei Rabelo. A teoria penal de P. J. A. Feuerbach e os juristas brasileiros do século XIX: a construção do direito penal contemporâneo na obra de 
P. J. A. Feuerbach e sua consolidação entre os penalistas no Brasil. Tese (Doutorado em Direito) - Faculdade de Direito da Universidade de São Paulo, São Paulo, 2008. RAMALHO, Joaquim Ignácio. Elementos do processo criminal para uso das Faculdades de direito do império, São Paulo: Typographia Dous de Dezembro, 1856.

SBRICCOLI, Mario. La penalistica civile. Teorie e ideologie del diritto penale nell'Italia unita. In: SBRICCOLI, Mario. Storia del diritto penale e della giustizia, Milão: Giuffrè, v. 2, p. 493-590, 2009.

SBRICCOLI, Mario. Justiça Criminal. Discursos Sediciosos, Rio de Janeiro: Revan, n. $17 / 18$, p. 459-486, 2011.

SOUZA, Braz Florentino Henriques de. Codigo criminal do Imperio do Brasil: annotado com as leis, decretos, avisos e portarias, Recife: Typ. Universal, 1858.

TOMAS Y VALIENTE, Francisco. El perdón de la parte ofendida en el Derecho penal castellano (siglos XVI, XVII y XVIII). In: Anuario de historia del derecho español, n. 31, p. 55-114, 1961.

\section{Informações adicionais e declarações dos autores (integridade científica)}

Declaração de conflito de interesses (conflict of interest declaration): o autor confirma que não há conflitos de interesse na realização das pesquisas expostas e na redação deste artigo.

Declaração de autoria e especificação das contribuições (declaration of authorship): todas e somente as pessoas que atendem os requisitos de autoria deste artigo estão listadas como autores; todos os coautores se responsabilizam integralmente por este trabalho em sua totalidade.

Declaração de ineditismo e originalidade (declaration of originality): o autor assegura que o texto aqui publicado não foi divulgado anteriormente em outro meio e que futura republicação somente se realizará com a indicação expressa da referência desta publicação original; também atesta que não há plágio de terceiros ou autoplágio. 


\section{Dados do processo editorial}

(http://www.ibraspp.com.br/revista/index.php/RBDPP/about/editorialPolicies)

- Recebido em: 29/12/2018

Equipe editorial envolvida

- Controle preliminar e verificação de plágio:

- Editor-chefe: 1 (VGV) 08/01/2019

- Avaliação 1: 09/01/2019

- Editor-assistente: 1 (ELL)

- Avaliação 2: 09/01/2019

- Revisores: 3

- Avaliação 3: 21/01/2019

- Decisão editorial preliminar: 22/01/2019

- Retorno rodada de correções: 01/02/2019

- Decisão editorial final: 05/02/2019

\section{COMO CITAR ESTE ARTIGO:}

TEIXEIRA, Arley F. O perdão do ofendido na cultura jurídico-penal brasileira do século XIX: negociação no século da justiça pública? Revista Brasileira de Direito Processual Penal, Porto Alegre, vol. 5, n. 1, p. 299-338, jan./abr. 2019.

https://doi.org/10.22197/rbdpp.v5i1.213

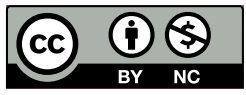

Esta obra está licenciada com uma Licença Creative Commons Atribuição-NãoComercial 4.0 Internacional. 